\title{
War and Stature: Growing Up during the Nigerian Civil War
}

\author{
By Richard Akresh, Sonia Bhalotra, Marinella Leone, and Una OKonkwo Osili*
}

The Nigerian civil war was the first modern war in sub-Saharan Africa after independence, and one of the bloodiest. It raged in Biafra, the secessionist region in the southeast of Nigeria from July 6, 1967 to January 15, 1970, killing between 1 and 3 million people and causing widespread malnutrition and devastation. We investigate the impact of exposure to the war as reflected in adult height, a latent stock measure of health. A number of studies establish adult height as a marker of the nutritional environment in early childhood, and environmentally determined variation in height predicts longevity, education, earnings, and the health of the next generation (Strauss and Thomas 1998; Case and Paxson 2008, 2010; Bhalotra and Rawlings 2011).

We estimate a difference-in-differences model, interacting an indicator for war-exposed ethnicity with a continuous cohort-based measure of months of exposure to the war. We find that the full consequences of this war are still being realized, some 30 to 40 years later. Individuals exposed to the war as children and adolescents, who are still alive today, exhibit reduced stature. A striking finding is that the impact of war exposure in adolescence is stronger than at younger ages.

This paper contributes to an emerging literature on the legacies of war in producing evidence of its long-run human capital costs. Estimates of the costs of war are pertinent given the increase in the incidence of conflict in the decades fol-

\footnotetext{
*Akresh: University of Illinois at Urbana-Champaign, Department of Economics, 1407 West Gregory Drive, David Kinley Hall, Room 214, Urbana, IL 61801 (e-mail: akresh@illinois.edu); Bhalotra: Department of Economics, University of Bristol, 8 Woodland Road, Bristol BS8 1TN, UK (e-mail: s.bhalotra@bristol.ac.uk); Leone: University of Sussex, Sussex House, Brighton, BN1 9RH, UK (e-mail: m.a.leone@sussex.ac.uk); Osili: Department of Economics, Indiana University-Purdue University Indianapolis, Indianapolis, IN 46202 (e-mail: uosili@iupui.edu).

$\dagger$ To view additional materials, visit the article page at http://dx.doi.org/10.1257/aer.102.3.273.
}

lowing the Biafran war. Civil war has afflicted a third of all nations in the past half-century. This paper is related to a growing body of work on the long-run impacts of fetal and childhood shocks (Almond and Currie 2011) and critical periods for investments in children (Cunha and Heckman 2007). We depart from previous studies in allowing for the fact that height experiences a second growth spurt during adolescence. Recent studies in economics recognize that adolescence may be a critical period in height formation (Case and Paxson 2008), but there is limited (causal) evidence of the consequences of nutritional deprivation at this age.

\section{Data and Methodology}

The Nigerian Demographic and Health Surveys (NDHS) are large nationally representative cross-sections with information for women aged 15 to 49 at the date of the survey. Heights are measured by trained surveyors, producing more reliable data than from self-reported measures of the stock of health. We use the most recent survey rounds of 2003 and 2008, which allow us to include cohorts who were adolescents during the war (the oldest cohort in the sample was born in 1954). We restrict the estimation sample to birth cohorts 1954-1974. We note that the sample only includes women who survived the war and this will tend to lead us to underestimate its impact. The main estimated equation is height $_{\text {imcesr }}=\beta_{a}$ war $_{\text {mce }}+\alpha_{c}+\delta_{a} m_{m c}+\theta_{e}+$ $\lambda_{s}+\mu_{r}+\gamma_{e} . t+u_{\text {imces }}$.

The subscripts $i, m, c, e, s$, and $r$ index an individual woman $i$ of birth month $m$ and birth year $c$ of ethnicity $e$ born in state $s$ whose height is measured in round $r$. The main variable of interest, $w r_{m c e}$, is specified as the interaction term, (war-exposed ethnicity) $\times$ (months of war exposure $)_{m c}$. The equation includes fixed effects for ethnicity, $\theta_{e}$, and birth year, $\alpha_{c}$, and it additionally includes (uninteracted) months of war exposure $\left(m_{m c}\right)$. We control for ethnicity-specific linear trends, 
$\gamma_{e} . t$, to allow for any underlying divergence or convergence in height across ethnic groups. Although there is a strong overlap of ethnicity and state, they are not identical, so we also include state fixed effects, $\lambda_{s}$. Survey round fixed effects, $\mu_{r}$, are included to allow, for instance, for any life cycle changes across cohort.

The coefficients $\beta_{a}$ and $\delta_{a}$ vary with the age at which the individual was exposed to the war. Importantly, this allows for the possibility that being exposed to the war for one year at age one could be more damaging than being exposed for the same duration but at age seven. The coefficients $\beta_{a}$ indicate the causal impact of the war under the standard identifying assumptions in a difference-in-differences model. The coefficients $\delta_{a}$ capture spillovers; in particular, they tell us whether the "untreated" ethnic groups suffer reduced stature from being alive during the war. The full impact of the war on the warexposed ethnicities for a given age cohort, $a$, is $\delta_{a}+\beta_{a}$. The equation is estimated by OLS and standard errors are clustered at the ethnicity-year level. We discuss below an alternative indicator for the treated group that proxies the intensity of the war by ethnicity (see the notes to Table 2). The rest of this section discusses our identification of the ethnic groups exposed to the war and our definition of a cohort-specific measure of exposure duration. Robustness checks on our identifying assumptions are presented in the results section.

Exposed Ethnicity.-The underlying causes of the Nigerian civil war are complex (KirkGreene 1971). The war was precipitated by the (predominantly Christian) southeastern region's declaration of independence from the rest of the country, leading to the formation of the Republic of Biafra. The war was fought in the southeast and direct civilian exposure to the war was largely restricted to this region. This region also witnessed the greatest food shortages. Given the importance of protein in height formation (Moradi 2010), it is relevant to note that Biafra imported protein prior to the war and these imports collapsed during the war (Aall 1970). Biafra was populated by the Igbo and other minority ethnic groups (who, together, accounted for about a fourth of the population), and so we define these as the war-exposed group. Many of the Igbo who lived outside of Biafra before the war fled to it for refuge once the war started. It is estimated that Biafra received 1.5 million refugees (Aall 1970). We focus on ethnicity in measuring war exposure, because a geography-based demarcation is sensitive to migration, although the results are consistent if we define treatment using geographic regions.

\section{Cohort and Age-Specific Exposure} Duration.-We use information on the month and year of birth to construct duration of exposure to the war in months, allowing heterogeneity in the exposure coefficients by age. To smooth over measurement error in age and gain precision, we define five age ranges, namely, the fetal year and ages 0-3, 4-6, 7-12, and 13-16. Age banding also allows for slight variation in the timing of the early childhood and pubertal growth spurts that, even in nonwar conditions, will arise from differences in baseline socioeconomic status across girls (Case and Paxson 2008).1 The control group consists of postwar births from November 1970 (nine months after the end of the war to avoid in utero war exposure) up until December 1974. We select a narrow window for the control group since the potential for confounding events increases with window size.

\section{Results}

The coefficients on the treatment variable $\left(\right.$ war $\left._{\text {mce }}\right)$ are statistically significant for each age band (Table 1). The point estimates are not significantly different between the fetal year and age 12. There is, however, a significant increase in the coefficient at age 13-16. War-exposed girls who were $0-3$ years of age during the war had an average exposure of 17.5 months and, for average exposure, suffered a reduction in adult height of 0.75 centimeters relative to unexposed girls of the same cohort. Exposure duration does

\footnotetext{
${ }^{1}$ The age bands are constructed with reference to the age profile of height growth (e.g., Case and Paxson 2008, Figure 3). Growth is rapid until age 3 and then relatively stable until adolescence (at about six $\mathrm{cm}$ per year), at which point it tends to experience a jump (to about ten $\mathrm{cm}$ per year) (Beard and Blaser 2002). Consistent with this age profile of growth velocity, height-for-age $Z$-scores for girls in Ghana and Cote d'Ivoire fall below a reference population of wellresourced children before the age of 3 and after the age of 11 but they track the reference in the intervening age interval (Moradi 2010). Our overall findings are not sensitive to small changes in the age boundaries.
} 
TABLE 1-Difference-IN-Differences Estimates of the IMPACT OF WAR ON STATURE

Duration of Exposure to War $\times$ Exposed Ethnicity

\begin{tabular}{|c|c|c|}
\hline Dependent variable: adult height & (1) & $(2)$ \\
\hline $\begin{array}{l}\text { Months exposure in utero } \\
\times \text { war ethnicity }\end{array}$ & $\begin{array}{r}-0.027 \\
(0.030)\end{array}$ & $\begin{array}{r}-0.047 \\
(0.038)\end{array}$ \\
\hline $\begin{array}{c}\text { Months exposure at ages } \\
0-3 \times \text { war ethnicity }\end{array}$ & $\begin{array}{l}-0.028 * * * \\
(0.009)\end{array}$ & $\begin{array}{c}-0.043 * * \\
(0.021)\end{array}$ \\
\hline $\begin{array}{l}\text { Months exposure at ages } \\
4-6 \times \text { war ethnicity }\end{array}$ & $\begin{array}{c}-0.035^{* *} \\
(0.014)\end{array}$ & $\begin{array}{r}-0.061^{*} \\
(0.034)\end{array}$ \\
\hline $\begin{array}{l}\text { Months exposure at ages } \\
7-12 \times \text { war ethnicity }\end{array}$ & $\begin{array}{l}-0.054 * * * \\
(0.011)\end{array}$ & $\begin{array}{c}-0.094 * \\
(0.050)\end{array}$ \\
\hline $\begin{array}{l}\text { Months exposure at ages } \\
13-16 \times \text { war ethnicity }\end{array}$ & $\begin{array}{l}-0.162 * * * \\
(0.033)\end{array}$ & $\begin{array}{l}-0.220 * * * \\
(0.076)\end{array}$ \\
\hline Months exposure in utero & $\begin{array}{r}-0.087 \\
(0.059)\end{array}$ & $\begin{array}{r}-0.081 \\
(0.060)\end{array}$ \\
\hline Months exposure at ages $0-3$ & $\begin{array}{l}-0.129 * * * \\
(0.034)\end{array}$ & $\begin{array}{l}-0.125^{* * * *} \\
(0.034)\end{array}$ \\
\hline Months exposure at ages 4-6 & $\begin{array}{c}-0.022 \\
(0.070)\end{array}$ & $\begin{array}{c}-0.015 \\
(0.071)\end{array}$ \\
\hline Months exposure at ages $7-12$ & $\begin{array}{r}-0.014 \\
(0.083)\end{array}$ & $\begin{array}{r}-0.003 \\
(0.083)\end{array}$ \\
\hline Months exposure at ages $13-16$ & $\begin{array}{r}-0.038 \\
(0.138)\end{array}$ & $\begin{array}{r}-0.022 \\
(0.137)\end{array}$ \\
\hline State fixed effects & Yes & Yes \\
\hline Ethnicity fixed effects & Yes & Yes \\
\hline Year fixed effects & Yes & Yes \\
\hline Ethnicity time trends & No & Yes \\
\hline Number of women & 13,407 & 13,407 \\
\hline
\end{tabular}

Notes: Robust standard errors in parentheses, clustered at the ethnicity $\times$ year level. In addition to the named fixed effects, regressions include a survey year dummy. The sample includes adult women born between 1954 and 1974 . Ethnicity time trends are defined by an interaction between ethnicity category and birth year. War ethnicity equals 1 if the individual belongs to the Igbo ethnicity or to another southeastern minority. The mean height in the sample is $158.70 \mathrm{~cm}$ and the standard deviation is 7.06 . The mean [standard deviation] of exposure duration in months (for the exposed ethnicities) at ages $-1,0-3,4-6,7-12$, and 13-16 is 7.3 [2.4], 17.5 [9], 17.9 [8.6], 23 [9.9], and 20.6 [10.8], respectively.

*** Significant at the 10 percent level.

** Significant at the 5 percent level.

* Significant at the 1 percent level.

not vary much with age and girls aged 4 to 12 during the war register impacts of similar size. The mean exposure duration at age 13-16 was 20.6 months and this led to a striking $4.53 \mathrm{~cm}$ deficit in height relative to unexposed women, which is two-thirds of the standard deviation of height in the estimation sample.
Interestingly, the estimates indicate that all Nigerian children who were $0-3$ years of age during the war suffered a long-term loss of stature. This is plausible since the war created country-wide food shortages, although these were more severe in the Igbo-dominated war region. Note that adding up the coefficients $\delta_{a}+\beta_{a}$ to get the full impact of the war on the exposed ethnicity produces an age gradient in impact that more closely corresponds to a typical growth velocity age profile (e.g., Figure 3 in Case and Paxson 2008).

The age gradient in the coefficients on war $_{\text {mce }}$, $\beta_{a}$, is possibly surprising given that the growth velocity, while elevated at both stages, is higher at age $0-3$ than at age 13-16. Even if growth is more rapid in early childhood than in adolescence, however, the increase in food demand may be greater for adolescents given their larger baseline size. A further potential explanation pertains to the age gradient in survival selection. ${ }^{2}$ Writing in the immediate aftermath of the war, an International Red Cross Committee official remarked, "In many of the hardest-hit areas, one hardly ever sees children aged between six months and five years. This is something which is immediately noticeable in a population in which normally up to 50 percent or more are children aged below 15 years" (Aall 1970). This author estimates that the number of births in the war regions fell by about half a million, suggesting that there was further selection into live births. In a manner of speaking, children exposed in utero and up until age five were a "lost generation."

Table 2 presents estimates using estimated excess mortality among the war-exposed ethnicities during the war. These estimates produce the same age gradient in war impact as is visible in Table 1 and, in fact, the same effect sizes (see the notes to Table 2). This is remarkable given that the mortality rates we used are estimated from self-reported sibling deaths and it suggests that our identification of the treated group based upon ethnicity, while simple, is accurate and powerful.

\footnotetext{
${ }^{2}$ In line with the risk of death declining sharply in age, positive selection of survivors is greater for individuals exposed to the war at age 0-3 than for individuals exposed at later ages. This will tend to play against scarring (Almond 2006; Bozzoli, Deaton, and Quintana-Domeque 2009).
} 
TABle 2-Difference-IN-Differences Estimates of the IMPACT OF War ON STATURE

Duration of Exposure to War $\times$ Excess Ethnic Group Mortality During the War

\begin{tabular}{lcc}
\hline \hline Dependent variable: adult height & $(1)$ & $(2)$ \\
\hline Months exposure in utero & -0.094 & -0.373 \\
$\quad \times$ ethnic mortality & $(0.221)$ & $(0.257)$ \\
Months exposure at ages & $-0.124^{*}$ & $-0.339^{* * *}$ \\
$0-3 \times$ ethnic mortality & $(0.064)$ & $(0.127)$ \\
Months exposure at ages & $-0.158^{*}$ & $-0.522^{* *}$ \\
4-6 $\times$ ethnic mortality & $(0.095)$ & $(0.217)$ \\
Months exposure at ages & $-0.320^{* * *}$ & $-0.866^{* * *}$ \\
7-12 $\times$ ethnic mortality & $(0.076)$ & $(0.294)$ \\
Months exposure at ages & $-0.848^{* *}$ & $-1.607^{* * *}$ \\
13-16 $\times$ ethnic mortality & $(0.346)$ & $(0.531)$ \\
Months exposure in utero & -0.045 & 0.108 \\
& $(0.137)$ & $(0.155)$ \\
Months exposure at ages 0-3 & -0.070 & 0.047 \\
& $(0.047)$ & $(0.076)$ \\
Months exposure at ages 4-6 & 0.054 & $0.252^{*}$ \\
& $(0.081)$ & $(0.137)$ \\
Months exposure at ages 7-12 & 0.145 & $0.441^{* *}$ \\
Months exposure at ages 13-16 & $(0.092)$ & $(0.181)$ \\
& 0.361 & $0.784 * *$ \\
State fixed effects & $(0.242)$ & $(0.317)$ \\
Ethnicity fixed effects & Yes & Yes \\
Year fixed effects & Yes & Yes \\
Ethnicity time trends & Yes & Yes \\
Number of women & No & Yes \\
\hline & 13,407 & 13,407 \\
\hline
\end{tabular}

Notes: See Notes to Table 1. The sample, as for Table 1, consists of female birth cohorts 1954-1974. Ethnic mortality is shorthand for the percentage change in mortality during the war (1967-1970) relative to a postwar period (1973-1976) among the war-exposed ethnicity (Igbo and other southeastern ethnicities). This is estimated from selfreported sibling death records and is set to zero for the control ethnicities. We have replaced the indicator for exposed ethnicity in Table 1 with this variable, interacting it with the individual woman's months of exposure to the war. The average difference between war-exposed and nonwarexposed ethnicities for mortality in wartime versus peacetime is 12 percent. Multiplying the coefficients in Table 2 by 0.12 delivers estimates that are very close to the coefficients in Table 1.

*** Significant at the 10 percent level.

**Significant at the 5 percent level.

* Significant at the 1 percent level.

Robustness Checks.-We conducted placebos on both ethnic group and cohort (results available on request). We created a placebo-treated group by defining an indicator for ethnicities in the central region, a region that was largely unin- volved in the war. We redefined the treatment variable, war $_{\text {mce }}$, as placebo $_{e} \times($ months exposed to the war $_{m c}$ and dropped the actual war-exposed ethnicities from the sample. We similarly conducted a placebo on cohorts by defining the war years as December 1983 to June 1986 (31 months, like the actual war, just 16 years later) and including cohorts 1970-1990 in the estimation, with the control group defined as cohorts 1987-1990. In neither case were any of the placebo treatment coefficients significant. These results mitigate potential concerns that our estimates of the impact of war are biased by differential trends that are not sufficiently accounted for by the inclusion of ethnicity-specific trends.

We investigated extending the control window up until 1990 and the reported coefficients remain comparable. If the health environment did not recover from the war immediately upon its cessation, our strategy of defining control cohorts from November 1970 onwards will tend to lead us to underestimate impact. We therefore reestimated the equations, dropping first 1971 and then 1971 and 1972 from the control group. The war $_{\text {mce }}$ coefficients rise, as expected, but are not significantly different.

\section{Conclusions}

Our investigation of the Biafran war of 1967-70 shows that several generations of Nigerian women, many of whom are alive today, carry the scars of their exposure to this war. The striking feature of our findings is that adult stature is more sensitive to the environment in adolescence than it is at younger ages. This is important since adolescent growth mediates the relationship between childhood stunting and adult stature. Our estimates (being derived from differencing across war-exposed and unexposed cohort and ethnicity) indicate the size of catchup growth that is feasible in nonemergency conditions. The extent of catch-up growth tends to increase with the extent of nutritional deficiency in childhood (Case and Paxson 2008). Thus, it being so large is consistent with girls who were 13-16 during the Biafran war being born in the early 1950 s into generally impoverished conditions.

The age gradient in the sensitivity of height to war exposure relates to recent debates on the height-wage premium that turn on whether the productivity of a given height advantage 
depends upon the age at which it is acquired. The evidence in Case and Paxson (2008), in contrast to that in Persico, Postlewaite, and Silverman (2004), suggests that, in the US and the UK, it is height growth in childhood that predicts wages. This is because nutritional insults in childhood lower cognitive ability and height is a marker for this. This may require modification in poorer countries where manual work is still important since even if adolescent growth only contributes "brawn," there are labor market returns to both "brain and brawn." The relative returns to brawn, however, appear to be larger for men than for women (Pitt, Rosenzweig, and Hassan 2010) and our estimates pertain to women. This said, adolescent growth in women may have an intergenerational payoff. There is limited evidence on these questions and our findings motivate further research on the genderspecific productivity loss associated with nutritional limitations on adolescent growth.

\section{REFERENCES}

Aall, Cato. 1970. "Relief, Nutrition and Health in the Nigerian/Biafran War." Journal of Tropical Pediatrics 16 (2): 70-90.

-Almond, Douglas. 2006. "Is the 1918 Influenza Pandemic Over? Long-Term Effects of In Utero Influenza Exposure in the Post-1940 U.S. Population." Journal of Political Economy 114 (4): 672-712.

-Almond, Douglas, and Janet Currie. 2011. "Killing Me Softly: The Fetal Origins Hypothesis." Journal of Economic Perspectives 25 (3): 15372.

- Beard, Albertine S. and Martin J. Blaser. 2002. "The Ecology of Height: The Effect of Microbial Transmission on Human Height."
Perspectives in Biology and Medicine 45 (4): 475-98.

- Bhalotra, Sonia, and Samantha B. Rawlings. 2011. "Intergenerational Persistence in Health in Developing Countries: The Penalty of Gender Inequality?" Journal of Public Economics 95 (3-4): 286-99.

-Bozzoli, Carlos, Angus Deaton, and Climent Quintana-Domeque. 2009. "Adult Height and Childhood Disease." Demography 46 (4): 647-69.

-Case, Anne, and Christina Paxson. 2008. "Stature and Status: Height, Ability, and Labor Market Outcomes." Journal of Political Economy 116 (3): 499-532.

-Case, Anne, and Christina Paxson. 2010. "Causes and Consequences of Early-Life Health." Demography 47: S65-85.

Cunha, Flavio, and James Heckman. 2007. "The Technology of Skill Formation." American Economic Review 97 (2): 31-47.

Kirk-Greene, Anthony H. M. 1971. Crisis and Conflict in Nigeria. New York: Oxford University Press.

-Moradi, Alexander. 2010. "Nutritional Status and Economic Development in Sub-Saharan Africa, 1950-1980." Economics and Human Biology 8 (1): 16-29.

-Persico, Nicola, Andrew Postlewaite, and Dan Silverman. 2004. "The Effect of Adolescent Experience on Labor Market Outcomes: The Case of Height." Journal of Political Economy 112 (5): 1019-53.

Pitt, Mark M., Mark R. Rosenzweig, and Nazmul Hassan. 2010. "Human Capital Investment and the Gender Division of Labor in a BrawnBased Economy." Unpublished.

Strauss, John, and Duncan Thomas. 1998. "Health, Nutrition, and Economic Development." Journal of Economic Literature 36 (2): 766-817. 